\title{
PENGARUH PEMBELAJARAN TEMATIK KELAUTAN TERHADAP PENANAMAN KARAKTER KEBAHARIAN PADA ANAK USIA 5-6 TAHUN DI TK HANG TUAH 12 SURABAYA
}

\author{
Candra Wardani ${ }^{1}$, Naili Sa'ida ${ }^{2}$, Ratno Abidin ${ }^{3}$ \\ ${ }^{2}$ nailisaida@fkip.um-surabaya.ac.id \\ 3abyratno@gmail.com \\ Jurusan Pendidikan Guru Pendidikan Anak Usia Dini FKIP, \\ Universitas Muhammadiyah Surabaya
}

\begin{abstract}
ABSTRAK
Penelitian ini untuk mengetahui pengaruh pembelajaran tematik kelautan terhadap anak usia 5-6 tahun di TK Hang Tuah 12 dan menjelaskan karakter anak usia 5-6 tahun di TK Hang Tuah 12 Surabaya sebelum dan sesudah pembelajaran tematik kelautan sehingga dari pembelajaran ini dapat diterapkan pendidikan yang berhubungan dengan lingkungan kelautan dalam menanamkan rasa cinta bahari sejak dini. Teknik pengumpulan data yang digunakan dalam penelitian ini adalah observasi dan dokumentasi. Analisis data dalam penelitian menggunakan Uji Wilcoxon Match Pairs untuk menguji uji beda dua sampel yang berhubungan. Uji ini melibatkan satu populasi penelitian kelompok B TK Hang Tuah 12 Surabaya. Berdasarkan hasil analisis data bahwa pembelajaran tematik kelautan memiliki pengaruh dalam penanaman karakter kebaharian pada anak usia 5-6 tahun di TK Hang Tuah 12 Surabaya. Hasil analisis data diperoleh Thitung sebesar 0 dan $T$ tabel sebesar 16, karena $0<16$ maka Ha diterima dan Ho ditolak. Hasil penelitian menunujukkan bahwa hasil posttest meningkat sangat baik dibandingkan dengan hasi pretest. Posttest ini mendapat hasil rata-rata 54,6 dari 15 peserta didik yang terlibat dalam kelompok sampel penelitian. Hal ini dapat disimpulkan bahwa pembelajaran tematik kelautan mempengaruhi penanaman karakter kebaharian pada anak usia dini. Pembelajaran tematik kelautan merupakan langkah yang tepat dan efektif dalam mengatasi rendahnya semangat dan jiwa bahari bangsa Indonesia. Dengan pembelajaran tematik kelautan peserta didik mendapatkan stimulasi atau informasi terkait dengan lingkungan kelautan sehingga mereka akan peka terhadap lingkungan tersebut.
\end{abstract}

Kata kunci: pembelajaran tematik kelautan; karakter kebaharian; anak usia dini

ABSTRACT
This study is to determine the effect of marine thematic learning on children aged 5-6 years at
Hang Tuah 12 Kindergarten and explain the character of children aged 5-6 years at Hang Tuah
12 Surabaya Kindergarten before and after marine thematic learning so that from this learning
applicable education can be applied with the marine environment in instilling a sense of marine
love from an early age. Data collection techniques used in this study were observation and
documentation. Data analysis in the study used the Wilcoxon Match Pairs Test to test the
difference test of two related samples. This test involved a study population of group B TK Hang
Tuah 12 Surabaya. Based on the results of data analysis that thematic marine learning has an
influence in the cultivation of maritime character in children aged 5-6 years at kindergarten Hang
Tuah 12 Surabaya. The results of data analysis obtained T count of 0 and Table of 16, because 0
$<16$ then Ho is accepted and Ho is rejected. The results showed that the posttest results improved
very well compared to the results of the pretest. This posttest received an average of 54.6 out of 15
students involved in the study sample group. It can be concluded that marine thematic learning
influences the cultivation of maritime character in early childhood. Marine thematic learning is
an appropriate and effective step in overcoming the low spirit and maritime spirit of the


Indonesian people. With marine thematic learning students get stimulation or information related to the marine environment so that they will be sensitive to the environment.

Keywords: marine thematic learning; maritime character; early childhood

\section{PENDAHULUAN}

Berdasarkan letak geografis, Indonesia adalah Negara kepulauan terbesar di dunia. Dari keseluruhan wilayah yang ada 2/3 dikelilingi oleh laut. Indonesia dapat dikatakan negara maritim karena sebagian besar aktivitas keseharian rakyatnya menjadikan laut sebagai ruang hidup sekaligus cara hidup mereka untuk mencari nafkah. Laut Indonesia memiliki potensi sumberdaya hayati maupun non hayati yang sangat besar sehingga dapat memberikan kontribusi yang sangat besar pula bagi perekonomian negara apabila dikelola dengan baik. Oleh karena itu, sudah saatnya bangsa Indonesia merubah paradigma dari negara agraris menjadi negara maritim.

Seiring dengan arah kebijakan pembangunan Indonesia saat ini, dimana laut menjadi faktor yang sangat penting dalam mendukung pembangunan khususnya di sektor ekonomi, maka dibutuhkan sumber daya manusia yang memiliki karakter dan jiwa bahari serta berwawasan maritim. Dalam konteks ini, pendidikan tentang kebaharian yang diimplementasikan dalam pembelajaran tematik kelautan sangat dibutuhkan dalam menanamkan karakter kebaharian. Usia 4-6 tahun merupakan masa peka bagi anak-anak untuk mendapatkan pendidikan. Pengalaman yang diperoleh anak dari lingkungan, merupakan stimulasi yang kita berikan yang akan berpengaruh pada masa depannya. Oleh karena itu diperlukan upaya yang mampu memfasilitasi mereka dalam mengembangkan aspek-aspek yang ada pada dirinya seiring dengan usia, kebutuhan, dan minat anak.

Usia dini memiliki peran yang besar dalam proses peletakan dasar pendidikan generasi masa mendatang. Pendidikan usia dini merupakan tahap awal proses pendidikan yang diselenggarakan secara terstruktur dalam upaya pembentukan sumber daya manusia dan bahari di Indonesia agar kelak menjadi generasi yang mampu bersaing di era globalisasi. Kearifan lokal kebaharian memotivasi anak untuk bergerak dan berperan langsung dalam memanfaatkan potensi dan sumber daya bahari melalui kreatifitas anak dan guru dalam pembelajaran tematik kelautan.

Saat ini anak-anak kurang memiliki kepedulian dan kepekaan pada lingkungan. Anak yang kurang mendapatkan stimulasi atau informasi terkait dengan lingkungan kelautan menjadi kurang peka terhadap lingkungan laut. Menurut Doni Koesoma (2011), pendidikan adalah proses penyaluran nilai budaya ke dalam diri seseorang dan masyarakat sehingga orang dan masyarakat menjadi beradab. Pendidikan tidak hanya transfer ilmu pengetahuan saja, tetapi lebih ke penanaman nilai-nilai karakter yang meliputi komponen pengetahuan, kesadaran atau kemauan, dan tindakan untuk melaksanakan nilai-nilai tersebut. Berdasarkan observasi awal yang dilakukan pada anak usia 5-6 tahun di TK Hang Tuah 12 Surabaya, terlihat anak-anak lemah dalam nilai-nilai dan jiwa bahari, terkait dengan lingkungan kelautan anakanak kurang peka terhadap lingkungan tersebut. Sehingga pada akhirnya mereka 
kurang dan tidak peduli terhadap lingkungan kelautan. Anak-anak usia 5-6 tahun TK Hang Tuah 12 belum memahami ekosistem laut, belum memahami dan tidak peduli menjaga lingkungan laut, belum mampu menjaga kelestarian alam wilayah laut, belum memahami cara memanfaatkan potensi laut dan rendahnya karakter kebaharian kecintaan terhadap laut. Oleh karena itu perlunya pembelajaran tematik kelautan dalam penanaman karakter kebaharian di TK Hang Tuah 12 Surabaya. Berdasarkan permasalahan ini penelitian ini bertujuan untuk mengetahui pengaruh pembelajaran tematik kelautan terhadap anak usia 5-6 tahun di TK Hang Tuah 12 dan menjelaskan karakter anak usia 5-6 tahun di TK Hang Tuah 12 Surabaya sebelum dan sesudah pembelajaran tematik kelautan sehingga dari pembelajaran yang diterapkan dapat menanamkan rasa cinta bahari sejak dini.

\section{METODE PENELITIAN}

Penelitian yang dilakukan adalah penelitian jenis penelitian kuantitatif dengan desain penelitian pre-eksperimen dengan desain One Group Pre-Test - PostTest, desainnya sebagai berikut:

\section{Desain Penelitian}

\begin{tabular}{|c|c|c|}
\hline Pre Test & $\begin{array}{c}\text { Variabel } \\
\text { Terikat }\end{array}$ & Post Test \\
\hline O1 $_{1}$ & $\mathrm{X}$ & $\mathrm{O}_{2}$ \\
\hline
\end{tabular}

\section{Keterangan :}

$\mathbf{X}=$ Perlakuan (treatment) pembelajaran tematik kelautan

O1 = Kemampuan sosial anak sebelum treatment

O2 = Kemampuan sosial anak setelah treatment
Teknik pengumpulan data yang digunakan dalam penelitian ini adalah observasi dan dokumentasi. Analisis data dalam penelitian menggunakan Uji Wilcoxon Match Pairs untuk menguji uji beda dua sampel yang berhubungan. Tanda positif dan negatif dari selisih pasangan data yang kemudian diranking inilah yang dipergunakan dalam analisis uji Wilcoxon Match Pairs. Uji ini melibatkan satu populasi penelitian yaitu TK Hang Tuah 12 Surabaya dan kelompok B sebagai sampelnya. Perbandingan selisih akan diuji menggunakan pre test dan post test untuk mengetahui peringkat-peringkatnya.

\section{HASIL DAN PEMBAHASAN}

\begin{tabular}{|c|c|c|c|c|c|c|c|}
\hline \multirow[t]{2}{*}{ No } & \multirow[t]{2}{*}{ Nama } & \multirow[t]{2}{*}{$\mathrm{X}_{\mathrm{A} 1}$} & \multirow[t]{2}{*}{$\mathrm{X}_{\mathrm{B} 1}$} & \multirow{2}{*}{$\begin{array}{c}\text { Beda } \\
X_{\mathrm{B} 1-} \\
\mathrm{X}_{\mathrm{A} 1}\end{array}$} & \multicolumn{3}{|c|}{ Tanda Jenjang } \\
\hline & & & & & $\begin{array}{c}\text { Jenjan } \\
\mathrm{g}\end{array}$ & + & - \\
\hline 1. & Anra & 19 & 35 & 16 & 13 & 13 & 0 \\
\hline 2. & Fatih & 20 & 35 & 15 & 11 & 11 & 0 \\
\hline 3. & Erick & 19 & 35 & 16 & 13 & 13 & 0 \\
\hline 4. & Alifa & 20 & 34 & 14 & 9,5 & $\begin{array}{l}9 \\
5\end{array}$ & 0 \\
\hline 5. & Chiera & 20 & 36 & 16 & 13 & 13 & 0 \\
\hline 6. & Nuel & 18 & 36 & 18 & 15 & 15 & 0 \\
\hline 7. & Althaf & 19 & 32 & 13 & 7 & 7 & 0 \\
\hline 8. & Alkaf & 21 & 32 & 11 & 2 & 2 & 0 \\
\hline 9. & Ais & 20 & 32 & 12 & 4,5 & $\begin{array}{l}4, \\
5\end{array}$ & 0 \\
\hline 10. & Rara & 18 & 32 & 14 & 9,5 & $\begin{array}{l}9, \\
5\end{array}$ & 0 \\
\hline 11. & Jova & 19 & 30 & 11 & 2 & 2 & 0 \\
\hline 12. & $\begin{array}{l}\text { Khrisn } \\
\text { a }\end{array}$ & 20 & 32 & 12 & 4,5 & $\begin{array}{l}4, \\
5\end{array}$ & 0 \\
\hline 13. & Amma & 19 & 32 & 13 & 7 & 7 & 0 \\
\hline
\end{tabular}




\begin{tabular}{|c|c|c|c|c|c|c|c|}
\hline & $\mathrm{r}$ & & & & & & \\
\hline 14. & Izan & 19 & 32 & 13 & 7 & 7 & 0 \\
\hline 15. & $\begin{array}{l}\text { Melvi } \\
\mathrm{n}\end{array}$ & 19 & 30 & 11 & 2 & 2 & 0 \\
\hline \multicolumn{6}{|c|}{ Jumlah } & $\begin{array}{l}\mathrm{T}_{+} \\
=1 \\
20\end{array}$ & $\begin{array}{l}\text { T- } \\
=0\end{array}$ \\
\hline
\end{tabular}

Data dalam penelitian pembelajaran tematik kelautan diambil dari hasil observasi yang terdiri dari 9 butir, diantaranya: tanya jawab tentang laut, tidak buang sampah di laut, mengurutkan 1-10 dengan benda laut, bercerita tentang pahlawan bahari, menirukan gerakan nelayan melempar jala, bermain kompas, bernyanyi "Mari Beramairamai ke laut", buat bentuk biota laut, dan puzzle ikan. Observasi ini dilakukan ketika pretest dan posttest. Pretest dilakukan sebelum pemberian perlakuan (treatment) pada kelompok B. Sedangkan Posttest dilakukan setelah diberikannya perlakuan (treatment). Pretest dilakukan untuk mengetahui kemampuan awal anak sebelum dilakukan perlakuan (treatment). Pretest diberikan pada kelas B sebagai kelompok sasaran dalam penelitian yang dilaksanakan pada bulan Januari 2019. Data pretest diambil setelah instrumen data telah diuji kevalidan dan reliabilitasnya. Penilaian pretest dilakukan satu kali melalui non test. Berdasarkan hasil analisis data diperoleh $\mathrm{T}_{\text {hit }}=0$ dan $\mathrm{T}_{\text {tab }}=16$ dengan taraf signifikan 0,05 atau 5\%, sehingga $\mathrm{T}_{\text {hit }}<\mathrm{T}_{\text {tab }}$ yang berarti hipotesis awal $(\mathrm{H} \alpha)$ diterima dan hipotesis nihil $\left(\mathrm{H}_{0}\right)$ ditolak, menunjukkan terdapat pengaruh pembelajaran tematik kelautan terhadap penanaman karakter kebaharian pada kelompok B usia 5-6 tahun di TK Hang Tuah 12 Surabaya.

Berhasilnya penelitian ini menjawab teori yang dikemukakan oleh Gunarsa dan Gunarsa (2012) bahwa faktor yang dapat membangkitkan dan merangsang minat belajar adalah bahan belajar yang akan diajarkan kepada siswa. Bahan pelajaran yang menarik minat belajar siswa, akan sering dipelajari oleh siswa yang bersangkutan. Sebaliknya bahan pelajaran yang tidak menarik akan dikesampingkan. Menurutnya guru juga mempengaruhi munculnya minat belajar siswa. Artinya jika disekolah diajarkan materi kebaharian yang disampaikan dalam tematik, maka anak akan memiliki minat akan kebaharian. Dan selanjutnya, dikatakan juga guru guru mampu menyampaikan materi dengan menarik akan membuat siswa tertarik pada materi yang disampaikan. Artinya jika guru mampu menyampaikan materi pembelajaran kebaharian dengan menarik, maka siswa akan tertarik pada materi kebaharian. Mengacu pada muatan lokal tersebut sangat penting untuk menumbuhkan karakter dan semangat kebaharian pada anak usia dini. Beberapa hal yang dapat mempengaruhi respon anak salah satunya adalah kedekatan terhadap obyek dan informasi yang diperoleh oleh anak. Anak yang mendapatkan stimulasi atau informasi terkait dengan lingkungan kelautan menjadi peka terhadap lingkungan tersebut. Sehingga pada akhirnya memiliki karakter yang baik terhadap lingkungan kelautan. Pembelajaran tematik kelautan dalam kurikulum pendidikan nasional merupakan langkah yang tepat dalam mengatasi rendahnya semangat dan jiwa bahari bangsa Indonesia sehingga akan mampu membangun sikap serta wawasan anak didik terhadap kondisi geografis Indonesia sebagai bangsa maritim dalam bentuk negara kepulauan yang terbesar di dunia. Upaya untuk mengenalkan lingkungan terdekat dengan siswa yaitu kelautan, perlu dilakukan melalui pendidikan sejak dini. Salah satu upaya yang dapat dilakukan adalah melalui pendidikan 
di Taman Kanak-kanak, melalui tema-tema yang telah ditetapkan sesuai dengan kurikulum Taman Kanak-Kanak. Ada peningkatan minat kebaharian,anak-anak lebih peka terhadap lingkungan yang erat kaitannya dengan laut. Hal ini dapat disimpulkan pembelajaran tematik kelautan yang diterapkan efektif dalam penanaman karakter kebaharian pada anak usia 5-6 tahun di TK Hang Tuah 12 Surabaya.

\section{KESIMPULAN}

Berdasarkan hasil penelitian yang telah dilakukan, maka peneliti dapat memberikan kesimpulan sebagai berikut:

1. Berdasarkan hasil analisis data bahwa pembelajaran tematik kelautan memiliki pengaruh dalam penanaman karakter kebaharian pada anak usia 5-6 tahun di TK Hang Tuah 12 Surabaya. Hasil analisis data diperoleh $\mathrm{T}$ hitung sebesar 0 dan $\mathrm{T}$ tabel sebesar 16, karena $0<16$ maka $\mathrm{H} \alpha$ diterima dan Ho ditolak, sehingga dapat disimpulkan bahwa pembelajaran tematik kelautan mempengaruhi penanaman karakter kebaharian pada anak usia dini.

2. Metode pembelajaran yang digunakan diantaranya bercerita atau bercakapcakap, bermain peran, pemberian tugas, demonstrasi, tanya jawab, percobaan atau eksperimen, belajar di luar kelas, kunjungan dan karyawisata. Penggunaan metode pembelajaran sesuai dengan tuntutan proses pembelajaran,dengan mempertimbangkan berbagai aspek pembelajaran yang lain. Sedangkan prinsip pembelajaran yang digunakan pada pembelajaran tematik kelautan sama dengan yang digunakan pada kurikulum 2013. Dengan demikian pembelajaran tematik kelautan sangat efektif diterapkan karena di dalam pembelajaran tematik kelautan di susun dan di rancang secara terpadu sehingga tepat dalam mengatasi rendahnya semangat dan jiwa bahari bangsa Indonesia sehingga akan mampu membangun sikap serta wawasan anak didik terhadap kondisi geografis Indonesia sebagai bangsa maritim dalam bentuk negara kepulauan yang terbesar di dunia. dunia pendidikan upaya untuk mengenalkan lingkungan terdekat dengan siswa yaitu kelautan.

\section{SARAN}

Berdasarkan hasil penelitian yang telah dilakukan, maka peneliti dapat memberikan beberapa saran sebagai berikut:

1. Pembelajaran tematik kelautan dapat menumbuhkan karakter kebaharian pada anak usia dini di Taman KanakKanak. Pembelajaran tematik kelautan sangat tepat dalam penanaman karakter kebaharian, anak-anak lebih peka terhadap lingkungan yang erat kaitannya dengan laut. Dengan demikian pembelajaran tematik kelautan sangat efektif diterapkan untuk menanamkan karakter kebaharian pada anak usia dini di Taman Kanak-Kanak.

2. Adanya bukti bahwa pembelajaran tematik kelautan memiliki pengaruh yang signifikan terhadap penanaman karakter kebaharian pada anak usia 5-6 tahun di TK Hang Tuah 12 Surabaya, diharapkan guru dapat menerapkan pembelajaran tematik kelautan sebagai stimulasi terkait dengan lingkungan kelautan.

\section{DAFTAR PUSTAKA}

Gunarsa, Singgih D.G.2012. Dasar dan Teori Perkembangan Anak Jakarta: Gunung Mulia.

Media Maritim Indonesia Jalasena. Edisi No 4, Tahun VII/2007. Mengembalikan Kejayaan Maritim. 
Media Maritim Indonesia Jalasena. Edisi No

1, Tahun IX/2019. Mengembalikan

Kejayaan Maritim.

Moeslichatoen, 2004. Metode Pengajaran di

Taman Kanak-kanak. Jakarta:Rineka

Cipta.

Sulistiani, Wiwik dan Arya, Lutfi, Model

Pembelajaran Tematik Berbasis

Kelautan dan Kemaritiman pada

anak usia dini di PAUD Nonformal.

PENDIDIKAN YANG

MENUMBUHKAN INSAN

PEMBELAJAR ISBN: 978- 979-

3153-8

Tim Pokja Kebaharian Tingkat Taman

Kanak-Kanak Yayasan Hang Tuah

(2014). Materi Pendidikan

Longitudinal Kebaharian Taman

Kank-Kanak; Buku Pedoman Guru

dalam Pelaksanaan Kurikulum

Pendidikan Longitudinal Kebaharian.

Trianto, 2010. Mengembangkan Model Pembelajaran Tematik.

Jakarta:Prestasi Pustaka.

Trianto, 2013. Desain Pengembangan Pembelajaran Tematik: Bagi Anak Usia Dini TK/RA \& Anak Usia Dini Kelas Awal SD/MI. Jakarta: Kencana Prenada Media Group PSIKOLOGI. Vol. 39 (1): 112-120. 